\title{
Childhood trauma and the enduring consequences of forcibly separating children from parents at the United States border
}

\author{
Martin H. Teicher ${ }^{1,2}$
}

\begin{abstract}
Forcible separation and detention of children from parents seeking asylum in the United States has been decried as immoral and halted by court order. Babies and children have been separated and transported to facilities sometimes many miles away. Limited data on forced detention of unaccompanied minors reveal high incidence of posttraumatic stress, anxiety disorders, depression, aggression, and suicidal ideation. These consequences will be magnified in youths forcibly separated from their parents, particularly younger children who depend on attachment bonds for self-regulation and resilience. Studies exploring the neuropsychiatric consequences of traumatic stress have revealed consistent effects of early life stress on brain structure, function and connectivity, and the identification of sensitive periods, which occur throughout childhood when specific regions and pathways are strongly influenced by adversity. Studies of epigenetics, inflammation and allostatic load are similarly enhancing our awareness of the molecular mechanisms underpinning the long-term consequences of traumatic stress. We must consider effects on the developing brain, mind and body to appreciate the long-term consequences of policies that force separation and detention of children.
\end{abstract}

Keywords: Childhood trauma, Early life stress, Refugees, Migrants, Family separation, Psychopathology, Sensitive periods, Brain development, Adverse childhood experiences

\section{Background}

The 'zero-tolerance' immigration policy initiated by the Trump administration led, within a matter of months, to the forced removal of thousands of children from their parents who were incarcerated for crossing the border in an effort to legally seek asylum. Politicians on both sides of the political spectrum, as well as the Pope, the Office of the United Nations High Commissioner for Human Rights, American Medical Association, American Academy of Pediatrics, and American Psychiatric Association decried this action. Bowing to intense pressure, President Trump amended this policy by executive order, hoping that law would be modified to enable children to be detained indefinitely with their families. Instead, on June 27, 2018, a federal judge denied this request and ordered US immigration

\footnotetext{
Correspondence: martin_teicher@hms.harvard.edu

${ }^{1}$ Department of Psychiatry, Harvard Medical School, Boston, USA

2Developmental Biopsychiatry Research Program, McLean Hospital, 115 Mill
}

Street, Belmont, MA 02478, USA agents to cease separating parents and children, and to reunite families split up within 30 days, and children younger than 5 within 14 days.

As health professionals, we need to understand the ramifications of separating children from their parents, and speak out against policies that so endanger the mental and physical wellbeing of children and families.

\section{Impact of forcible separation and traumatic stress} Some argue that actions taken by the US Government were relatively inconsequential to detained children because, as asylum-seeking immigrants, these children and their families were fleeing their home countries in a desperate effort to avoid more dire consequences such as violence, imminent threats of death or trafficking. However, this ignores the enormous protective power of families.

Children are dependent on the adults around them for their survival, and they can endure great hardship in the presence of parents with whom they feel protected and

(c) The Author(s). 2018 Open Access This article is distributed under the terms of the Creative Commons Attribution 4.0 International License (http://creativecommons.org/licenses/by/4.0/), which permits unrestricted use, distribution, and reproduction in any medium, provided you give appropriate credit to the original author(s) and the source, provide a link to the Creative Commons license, and indicate if changes were made. The Creative Commons Public Domain Dedication waiver (http://creativecommons.org/publicdomain/zero/1.0/) applies to the data made available in this article, unless otherwise stated. 
cared for. Forcibly removing a child from their parents is one of the most profound traumas a child can experience, since it undermines a pivotal foundation they require for self-regulation and resilience [1]. Similarly, having your children forcibly taken, not knowing where they are, and not being allowed to contact them, is many parents' worst nightmare. Indeed, this is why members of the Trump administration advocated its use as a deterrent to immigration.

Some also question whether a few weeks or months of forced separation can have enduring effects. However, we know that brief traumatic events, such as being raped or witnessing violence to a loved one, can have life-long consequences [2]. Traumatic events are often betrayals of trust, or shatter our notions of safety and security. The impact of forced separation by the Trump administration will not end when children and parents are reunited. Many will live in fear that this will happen again, and this can have enduring epigenetic effects on the stress response system and attendant allostatic load - in turn increasing long-term risk for obesity, type 2 diabetes, chronic inflammation, and cardiovascular disease [3].

Clinically, evidence from studies of unaccompanied minors seeking asylum reveals that forced detention is associated with a high risk of posttraumatic stress disorder, anxiety disorder, depression, aggression, psychosomatic complaints, and suicidal ideation [4]. This is not surprising since adverse childhood experiences account for about $45 \%$ of the population-attributable risk for childhood onset psychiatric disorders [5]. One of the more disturbing features reported about the detention centers was their rule forbidding children from touching or hugging each other, including siblings.

\section{Sensitive exposure periods and brain development}

Nursing infants, toddlers, youths and teens have all been removed from their parents, and many will suffer a variety of age-specific psychiatric and neurobiological effects as a result. The central nervous system undergoes profound maturational changes during all stages of childhood, and various brain regions and pathways have their own unique sensitive periods during which experience can most dramatically shape and fine-tune their synaptic structure and interconnections. Studies in my laboratory and other centers have begun to identify the developmental stages at which specific structures are most vulnerable.

Regions especially susceptible to stress during the first seven postnatal years [6-10] are involved in detecting and responding to threats, and in the regulation of stress response. Modifying this system is one of the primary ways our brains are shaped by early adversity [11]. These regions are also involved in aspects of attention and memory, and these processes appear to be particularly vulnerable to adversity during early childhood [12].

Myelinating fiber pathways [13-15] and corticolimbic structures $[16,17]$ appear to be especially vulnerable during middle childhood. These pathways are critical for left-right hemispheric integration and sensory processing [11]. Which sensory systems, if any, may be affected by forced separation and detention, are not known but would likely depend on aspects of detention that children found most aversive. For example, in previous research by our laboratory, physical and emotional neglect at 11 years of age emerged as a key determinant of social cognition [12].

Brain regions affected by adversity during the peripubertal and teenage years are involved in emotional regulation, impulse control, and other executive functions [7, $13,18]$. Adversity is also associated with significant alterations in brain network organization, primarily through effects on late-maturing association pathways [19]. Emotional abuse around the age of 15 emerged in another of our studies as the most important predictor of risk for major depression [20].

\section{Psychopathology with and without early life stress}

Psychiatric disorders in individuals exposed to severe childhood stress have an earlier age of onset, more comorbidities, and a more severe course and poorer response to first line treatments than in unexposed individuals with the same primary psychiatric diagnosis [21]. They also have an array of neurobiological alterations [11] and signs of chronic inflammation [22] not found in their unexposed counterparts, which has led us to propose that psychiatric disorders presenting in individuals with early life stress represent a unique and clinically challenging ecophenotype (i.e., a modified phenotype resulting from environmental influences) [21]. Hence, children separated from families seeking asylum may be further burdened with difficult-to-treat disorders that emerge years later, particularly as they pass through puberty [11].

\section{Conclusions}

Safe, supportive and nurturing relationships with primary caregivers are critical for the healthy physical and emotional development of children. Parents play an essential role in enabling children already exposed to serious adversity to cope and effectively recover by buffering their stress response, facilitating their ability to self-regulate, and helping them to rebuild a sense of security [1]. Removing children from their parents is a governmental prerogative that should only be used after judicial review, and when necessary to protect children from harm from abusive or neglectful parents. 
It is sad to note that the United States implemented this inhumane policy, and is the only member country of the UN that has not ratified the United Nations Convention on the Rights of the Child. Leaders who advocated and advanced a policy tantamount to state sponsored child abuse should be held accountable. Anyone callous enough to treat children of refugees in this way can hardly be trusted to treat other people's children, even those of American citizens, in a wise and caring manner. Fortunately, recordings of inconsolable children crying released in the media touched enough hearts to show that there is a majority of Americans who care about children. Societies reap what they sow in terms of the way they treat their children - as well as the children of brave and resourceful asylum seekers eager to become part of the American experience. A nation striving for greatness would do well to keep this in mind.

\section{Funding}

Work on the effects of childhood adversity was funded by National Institute of Mental Health RO1 Award MH-091391, National Institute on Drug Abuse RO1 Award DA-017846, National Institute of Child Health and Human Development RO1 Award HD-079484, and by a donation from the ANS Foundation.

\section{Author's contributions}

MHT wrote the manuscript. The author read and approved the final manuscript.

\section{Ethics approval and consent to participate}

Not applicable.

\section{Consent for publication}

Not applicable.

\section{Competing interests}

The author declares that he has no competing interests.

\section{Publisher's Note}

Springer Nature remains neutral with regard to jurisdictional claims in published maps and institutional affiliations.

Received: 26 July 2018 Accepted: 6 August 2018

Published online: 22 August 2018

\section{References}

1. Mackenzie MJ, Bosk E, Zeanah CH. Separating families at the border consequences for children's health and well-being. N Engl J Med. 2017; 376(24):2314-5.

2. Van der Kolk BA. The body keeps the score: brain, mind and body in the healing of trauma. New York: Viking; 2014

3. McEwen BS. Early life influences on life-long patterns of behavior and health. Ment Retard Dev Disabil Res Rev. 2003;9(3):149-54.

4. Baily CDR, Henderson SW, Taub AR, O'Shea G, Einhorn H, Verdeli H. The mental health needs of unaccompanied immigrant children: lawyers' role as a conduit to services. Grad Student J Psychol. 2014;15:3-17.

5. Green JG, McLaughlin KA, Berglund PA, Gruber MJ, Sampson NA, Zaslavsky AM, et al. Childhood adversities and adult psychiatric disorders in the national comorbidity survey replication I: associations with first onset of DSM-IV disorders. Arch Gen Psychiatry. 2010;67(2):113-23.

6. Lyons-Ruth K, Pechtel P, Yoon SA, Anderson CM, Teicher MH. Disorganized attachment in infancy predicts greater amygdala volume in adulthood. Behav Brain Res. 2016;308:83-93.

7. Teicher MH, Anderson CM, Ohashi K, Khan A, McGreenery CE, Bolger $E A$, et al. Differential effects of childhood neglect and abuse during sensitive exposure periods on male and female hippocampus. Neurolmage. 2018;169:443-52.

8. Jensen SK, Dickie EW, Schwartz DH, Evans CJ, Dumontheil I, Paus T, et al. Effect of early adversity and childhood internalizing symptoms on brain structure in young men. JAMA Pediatr. 2015;169(10):938-46.

9. Rao H, Betancourt L, Giannetta JM, Brodsky NL, Korczykowski M, Avants BB, et al. Early parental care is important for hippocampal maturation: evidence from brain morphology in humans. Neurolmage. 2010;49(1):1144-50.

10. Luby JL, Belden A, Harms MP, Tillman R, Barch DM. Preschool is a sensitive period for the influence of maternal support on the trajectory of hippocampal development. Proc Natl Acad Sci U S A. 2016;113(20):5742-7.

11. Teicher MH, Samson JA, Anderson CM, Ohashi K. The effects of childhood maltreatment on brain structure, function and connectivity. Nat Rev Neurosci. 2016;17(10):652-66.

12. Schalinski I, Teicher MH, Carolus AM, Rockstroh B. Defining the impact of childhood adversities on cognitive deficits in psychosis: an exploratory analysis. Schizophr Res. 2018;192:351-6.

13. Andersen SL, Tomoda A, Vincow ES, Valente E, Polcari A, Teicher MH. Preliminary evidence for sensitive periods in the effect of childhood sexual abuse on regional brain development. J Neuropsychiatry Clin Neurosci. 2008;20(3):292-301.

14. Choi J, Jeong B, Polcari A, Rohan ML, Teicher MH. Reduced fractional anisotropy in the visual limbic pathway of young adults witnessing domestic violence in childhood. Neurolmage. 2012;59(2):1071-9.

15. Seckfort DL, Paul R, Grieve SM, Vandenberg B, Bryant RA, Williams LM, et al. Early life stress on brain structure and function across the lifespan: a preliminary study. Brain Imaging Behav. 2008;2:49-58.

16. Pechtel $\mathrm{P}$, Lyons-Ruth $\mathrm{K}$, Anderson $\mathrm{CM}$, Teicher MH. Sensitive periods of amygdala development: the role of maltreatment in preadolescence. Neurolmage. 2014;97:236-44.

17. Tomoda A, Polcari A, Anderson CM, Teicher MH. Reduced visual cortex gray matter volume and thickness in young adults who witnessed domestic violence during childhood. PLoS One. 2012;7(12):e52528.

18. Walsh ND, Dalgleish T, Lombardo MV, Dunn VJ, Van Harmelen AL, Ban M, et al. General and specific effects of early-life psychosocial adversities on adolescent grey matter volume. Neuroimage Clin. 2014;4:308-18.

19. Ohashi K, Anderson CM, Bolger EA, Khan A, McGreenery CE, Teicher MH Childhood maltreatment is associated with alteration in global network fiber-tract architecture independent of history of depression and anxiety. Neurolmage. 2017;150:50-9.

20. Khan A, McCormack HC, Bolger EA, McGreenery CE, Vitaliano G, Polcari A, et al. Childhood maltreatment, depression, and suicidal ideation: critical importance of parental and peer emotional abuse during developmental sensitive periods in males and females. Front Psychiatry. 2015;6:42.

21. Teicher MH, Samson JA. Childhood maltreatment and psychopathology: a case for ecophenotypic variants as clinically and neurobiologically distinct subtypes. Am J Psychiatry. 2013;170(10):1114-33.

22. Cohen-Woods S, Fisher HL, Ahmetspahic D, Douroudis K, Stacey D, Hosang GM, et al. Interaction between childhood maltreatment on immunogenetic risk in depression: discovery and replication in clinical case-control samples. Brain Behav Immun. 2017;67:203-10.
Ready to submit your research? Choose BMC and benefit from:
- fast, convenient online submission
- thorough peer review by experienced researchers in your field
- rapid publication on acceptance
- support for research data, including large and complex data types
- gold Open Access which fosters wider collaboration and increased citations
- maximum visibility for your research: over $100 \mathrm{M}$ website views per year
At $\mathrm{BMC}$, research is always in progress.
Learn more biomedcentral.com/submission 